\title{
Understanding Mediterranean Pasture Dynamics: General Tree Cover vs. Specific Effects of Individual Trees
}

\author{
José Manuel De Miguel, ${ }^{1}$ Belén Acosta-Gallo, ${ }^{2}$ and Antonio Gómez-Sal ${ }^{3}$ \\ Authors are ${ }^{1}$ Professor and ${ }^{2}$ Associate Professor, Departamento de Ecología, Universidad Complutense de Madrid, 28040 Madrid, Spain; and ${ }^{3}$ Professor, \\ Departamento de Ecología, Universidad de Alcalá, 28871 Alcalá de Henares, Madrid, Spain.
}

\begin{abstract}
The study investigated the effect of general and homogeneous tree cover on grassland composition on an extensive Mediterranean rangeland with sparse oak trees in central Spain. We analyzed this effect together with other significant factors identified in this type of rangeland: topography and plowing. Data were collected in the 1984 growing season and they form part of a historical database on the characteristics of vegetation and livestock behavior; these data refer to grasslands below and away from the tree crowns of 91 individual trees, located in different topographical positions and in areas that were last plowed at different times. We used multivariate analyses to identify the main compositional trends of variation in pasture communities. The results indicate that the herbaceous community below tree crowns was more similar to that of the lowland areas than to the nearby areas away from the tree. This result supports the idea of tree cover in semiarid rangelands as a factor attenuating the effects on pastures of environmental conditions typical of high and intermediate topographical positions—generally presenting low soil moisture and fertility. Coupled with this, we also found effects of some individual trees related with the way livestock uses them as shelter and resting places. Our results indicate that the role played by dispersed trees in the management of this type of rangeland should be analyzed at two complementary spatial scales: the overall effect of tree cover as a factor acting at landscape scale and the specific effect of some individual trees acting at a more detailed scale.
\end{abstract}

Key Words: free-ranging livestock, pasture management, Quercus ilex, scattered trees, silvopastoral systems, topography effect

\section{INTRODUCTION}

Traditional rangelands in Mediterranean climate regions include areas of savannah-like formations derived from preexisting forests, with dominant scattered trees forming an almost regular grid (Le Houérou 1981; Ovalle et al. 1990; Pineda and Montalvo 1995; Tate et al. 2004; Marañón et al. 2009). In these systems herbaceous cover is almost continuous, and scrub is eliminated or strongly controlled by regular plowing (Pérez-Ramos et al. 2008). Both the arboreal and herbaceous components represent two separate subsystems in interaction (Ovalle and Avendaño 1987; Scholes and Archer 1997; Sankaran et al. 2004; Gea-Izquierdo et al. 2010). The tree component, with slower turnover rates, plays a stabilizing role, whereas the herbaceous component represents the most productive and dynamic part of the system.

Most studies analyzing the main factors responsible for heterogeneity and productivity of pastures in these systems have focused upon areas without trees or far from the dispersed trees. Among these factors, time from last plowing event, topographical position, and grazing intensity are considered in many studies as the main factors responsible for the floristic variation and productivity of these pastures (Pineda et al. 1981a, 1981b; Casado et al. 1985; Peco 1989; Ovalle et al. 1990, 2006; Sternberg et al. 2000).

The existence of a regular tree network acts as a key structure for the maintenance of essential ecological func-

Correspondence: José Manuel De Miguel, Dept de Ecología, Universidad Complutense de Madrid, 28040 Madrid, Spain. Email: demiguel@bio.ucm.es

Manuscript received 7 February 2012; manuscript accepted 15 September 2012.

(c) 2013 The Society for Range Management tions-including biodiversity conservation-in rangeland ecosystems (Manning et al. 2006, 2009; Olea and San MiguelAyanz 2006; Reis et al. 2010). Beneath tree crowns, microclimatic conditions, edaphic characteristics, and animal behavior are different (Ovalle et al. 1990, 2006; Vetaas 1992; Belsky, 1994; Ludwig et al. 2008). In Mediterranean climates, isolated trees have a relevant effect on several aspects of pastures beneath them, such as composition and production (GonzálezBernáldez et al. 1969; Moreno 2008), biological diversity (Marañón 1986; Pineda and Montalvo 1995; Díaz and Cabido 1997), hydrological balance (Joffre and Rambal 1993; Cubera and Moreno 2007), nutrient cycles and other edaphic properties (Escudero et al. 1985; Hernández et al. 1992; Gallardo 2003; Moreno and Obrador 2007), and livestock behavior (De Miguel et al. 1997; De Miguel 1999).

Despite this evidence, few studies have attempted to evaluate the combined effect of trees with other significant ecological factors on floristic variability of pastures (Puerto and Rico 1989; Marañón et al. 2009). The present paper attempts to do so. We hypothesized that tree cover in savannah-like rangelands will have an influence on pasture composition greater in magnitude than other key ecological factors acting at the landscape scale, such as topography and the successional dynamics initiated after the land is plowed. In order to test for this we focused on a type of silvopastoral system with a network of sparsely distributed holm oaks (Quercus ilex) whose succesional and geomorphology dynamics are well known) (Pineda et al. 1981a; Marañón 1988; Peco 1989). In Spain, this kind of system is known as a "dehesa" and occupies an area of about 4 million ha and maintains high values of biological diversity (Pineda and Montalvo 1995; Marañón et al. 2009). 


\section{MATERIALS AND METHODS}

\section{Study Area}

The study area consists of a 3000 -ha estate, which forms part of the El Pardo forest $15 \mathrm{~km}$ north of Madrid. This area was a royal hunting estate in the 14th century, and since then has been subjected to varying levels of grazing pressure. As a result of its high conservation value, the whole El Pardo area was included in the 37000-ha Manzanares Natural Park in 1985, although the data we analyze here were obtained $1 \mathrm{yr}$ earlier, in 1984, when the estate was still undergoing a traditional management comprising cereal sowing, rotational plowing, tree pruning, hunting (mainly rabbits, common wood pigeons, red-legged partridges and, to a lesser extent, red deer and fallow deer), and extensive cattle raising (Gómez-Gutiérrez 1992; Olea and San Miguel-Ayanz 2006). Regarding the latter, a herd of about 400 cattle of the autochthonous breed AvileñaNegra Ibérica was kept in the estate year-round at that time, moving freely throughout the area but generally avoiding dense shrub zones (Gómez-Sal et al. 1992; De Miguel et al. 1997), and being supplied with fodder in summer (July-August) and winter (November-February), when grassland production was low. Currently, the management of this estate still involves silvopastoral practices, but management goals are mainly oriented to nature conservation, environmental education, and recreational purposes due to the proximity of this area to the city of Madrid. As a consequence, cattle numbers are much reduced while the sizes of red deer and fallow deer populations have increased.

Lithology is mainly arkosic sediments. Ridges and alluvial plains are connected by an extensive intermediate zone of valleys and slopes, resulting in an undulating relief with altitude ranging from $610 \mathrm{~m}$ to $720 \mathrm{~m}$ (De Miguel et al. 1997). The climate is continental Mediterranean with long dry summers and cold winters. Average annual rainfall is over 550 $\mathrm{mm}$ and mean annual temperature is $13^{\circ} \mathrm{C}$. Mean minimum and maximum temperatures range from $-7^{\circ} \mathrm{C}$ in January to $37^{\circ} \mathrm{C}$ in August.

The vegetation structure has typical dehesa characteristics. Dehesas are the result of the traditional agro-silvopastoral use of Mediterranean forests (Le Houérou 1981; Marañón 1988; Martín and Fernández-Alés 2006). The dehesa systems may cover an area of about 4 million ha in the south and centralwestern Iberian Peninsula (Olea and San Miguel-Ayanz 2006). They can be described as savannah-like formations with dominant scattered trees, mainly holm oaks (Quercus ilex), with variable tree densities (from 30 to 60 individuals per hectare). This species is replaced by ash (Fraxinus angustifolia) on alluvial plains. Pastures are dominated by annual plants.
Two species predominate in the scrub vegetation: Cistus ladanifer and Q. ilex. Herbaceous cover presents little variation, and scrub is controlled by regular plowing. The tree component of these ecosystems shows very low levels of regeneration, which has raised concerns about the long term persistence of the dehesas (Gómez-Gutiérrez 1992; Plieninger et al. 2003).

In these systems, pastures cover a wide area due to human control (periodic plowing, rye sowing with long fallow periods, oak pruning, and brushwood clearing) and the activity of freeranging grazers: cattle and game, including deer, fallow deer, and rabbits. Plowing initiates secondary succession in noncontinuous areas, with nonsystematic cycles that can exceed $30 \mathrm{yr}$. This results in a mosaic of pasture communities with differing degrees of maturity and high biological diversity (Pineda and Montalvo 1995; Marañón et al. 2009; Fernández-Moya et al. 2011).

\section{Experimental Design}

The data were extracted from a historical database of vegetation characteristics and livestock behavior in the study estate built by Departments of Ecology of the Autonomous and Complutense universities of Madrid from the late 1970s to the late 1980 s (data collection virtually stopped coinciding with a change of the estate ownership, and before management practices changed due to the integration of this area in the Manzanares Natural Park in 1985). From this database, a number of investigations are being published on many aspects of the structure and functioning of plant communities and their relationships with cattle activities, thus making this estate one of the best documented dehesa systems of Spain (Casado et al. 1985; Peco 1989; Pineda and Montalvo 1995; De Miguel et al. 1997).

The data we used were collected by us in 1984 between May and June, coinciding with the main growing period of the herbaceous species. Ninety-one sampling sites $(50 \times 50 \mathrm{~m})$ were selected according to two environmental conditions known to be important for dehesa pasture composition (Pineda et al. 1981a): topographical position and time since the last plowing event (hereafter TLP). Both variables were initially divided into three categories (Table 1). The sites were randomly distributed throughout the nine sectors resulting from the combination of these categories. The number of sites assigned to each sector was proportional to its corresponding area. In order to understand the specific tree-herbaceous pasture system and its interactions, those areas not grazed by livestock (Gómez-Sal et al. 1992), where scrub cover was dominant, were not included in the study. Alluvial plains dominated by ash trees were also excluded.

Table 1. Location of the 91 sampling sites according to three major topographical classes and three time periods since the last plowing. Two plots were sampled at each site: below the tree crown and away from it.

\begin{tabular}{lccr}
\hline & \multicolumn{3}{c}{ Time since last plowing } \\
\cline { 2 - 4 } \multicolumn{1}{c}{ Topographical position } & $<5 \mathrm{yr}$ & $5-26 \mathrm{yr}$ & \multicolumn{2}{c}{ Total } \\
\hline Upper zones (ridges, upper slope zones, high flat zones) & 13 & 6 & 2 \\
Intermediate zones (midslope zones) & 4 & 13 & 21 \\
Lower zones (lower slope zones, lowlands) & 14 & 14 & 13 \\
Total & 31 & 33 & 29 \\
\hline
\end{tabular}


At each $50 \times 50 \mathrm{~m}$ site, two $5 \times 5 \mathrm{~m}$ plots (approximately the average vertical projection of the crown of the trees) were selected: one below the crown of an isolated Q. ilex tree and another at least $10 \mathrm{~m}$ away from the tree, in the pasture matrix (far from the tree effect). These plots will be referred to as "tree" and "pasture" hereafter, respectively. Total number of plots was 182 .

In each plot, herbaceous species abundance was estimated in four randomly distributed $20 \times 20 \mathrm{~cm}$ quadrats (at tree plots, the quadrats were separated at least $1 \mathrm{~m}$ from the tree trunk, as this area is usually not plowed) and according to six percentage cover classes; namely, $0 \%, 0-1 \%, 1-10 \%, 10-25 \%, 25-50 \%$, and $>50 \%$. As a quantitative value of species abundance, the mean cover value of each class- $0 ; 0.5 ; 5.5 ; 17.5 ; 37.5$, and 67.5-was used (Cottingham et al. 2005). For each species, the mean of the four quadrats of each plot was calculated.

In order to understand pasture variation, several environmental variables were recorded at each sampling site: slope, orientation, tree, scrub and herbaceous cover, topographical position, and TLP. In order to take into account the internal variability of each sampling site, the last two variables were recorded in greater detail than that reflected by the initial classification. Therefore, each site was assigned to each of six topographical classes: (ridges, upper slope zones, high flat zones, midslope zones, lower slope zones, and lowlands) and six TLP categories: $(<3 \mathrm{yr}, 3-5 \mathrm{yr}, 5-8 \mathrm{yr}, 8-26 \mathrm{yr}, 26-30$ years and $>30 \mathrm{yr}$ since the last plowing event). The values of the rest of variables were assigned to the following categories: slope (\%): $0-1,1-8,8-12,12-17,17-25,>25$; herbaceous and scrub cover $(\%)$ : $0,0-10,10-25,25-50,50-75,>75$; tree cover $(\%)$ : $0,0-10,10-25,>25$; orientation (degrees): $45-$ $135,135-225,225-315,315-45$.

Several studies have attributed the effect of trees on the pasture composition to the input of litter, soil variables, and the grazers'-cattle and game-behavior (Escudero et al. 1985; Gómez Sal et al. 1992; Malo and Suarez 1995; Gallardo 2003; Maltez-Mouro et al. 2005; Gea-Izquierdo et al. 2010; Fernández-Moya et al. 2011). Thus, another set of variables related to soil cover was also recorded in the plots: scrub and herbaceous plant cover, bare soil, holm oak scrub cover, total litter, cow dung pats, and rabbit pellets. Total litter was calculated as the sum of oak leaf litter, other leaf litter, catkins, and small twigs. We calculated the mean abundance of these variables in the plot as the average cover value recorded in each of the four $20 \times 20 \mathrm{~cm}$ quadrats. In each quadrat, the cover values were recorded according to the same six percentage cover classes as those for individual species, and the same quantitative estimation of the mean was used for statistical analyses.

Soil characteristics of plots were also quantified. For this purpose, four samples of approximately $15-\mathrm{cm}$ depth were collected in each plot and mixed into a single sample. Subangular structure and texture (Bouyoucos method), $\mathrm{pH}$ (Beckman potentiometer and glass electrode), electric conductivity (solution of $10 \mathrm{~g}$ of soil in $25 \mathrm{ml}$ of distilled water) with corrected values for $25^{\circ} \mathrm{C}$, and color and darkness of the soil (Munsell soil color charts) were measured in each case.

Species richness was calculated for each plot as the sum of all the different species found in the four $20 \times 20 \mathrm{~cm}$ quadrats. We also calculated average richness of the two groups of plots- tree and pasture plots-as the mean richness value recorded in the 91 plots of each group.

\section{Data Analyses}

Detrended correspondence analysis (DCA; Hill and Gauch 1980), in PC-ORD 4.1 (MjM Software, Gleneden Beach, OR, USA) was used to identify differences in vegetation composition between plots. DCA was applied due gradient length $>4$ standard deviations (Jongman et al. 1995). PC-ORD 4.1 software includes strict criteria suggested by Oksanen and Minchin (1997). The proportions of variance explained by DCA axes were evaluated by means of after-the-fact coefficients of determination between the relative Euclidean distance in the original space and Euclidean distance in the ordination space (MjM Software)

By means of correlation and regression analyses, linear and quadratic relationships between the coordinates of the plots on the axes of the DCA and both the abundance of species and the values of environmental variables (excepting orientation and soil color) recorded from plots and the sites were calculated. The relationship between orientation and soil color and the DCA axis was tested by means of ANOVA and post-hoc LSD tests. Parametric ( $r$ Pearson) and nonparametric ( $r$ Spearman) were used, but no significant differences were observed between them. Therefore, only $r$ Pearson results are reported. For these analyses, the cover values of environmental variables were square-root transformed. The average of each species and variable abundance between tree and pasture plots were compared by means of Student's $t$ test. Differences between mean DCA coordinate values of different plot types were tested using ANOVA and post-hoc LSD tests. All statistical analyses were performed using the statistical package SPSS 19.0.

\section{RESULTS}

\section{Characteristics of the Herbaceous Communities in Tree and Pasture Plots}

Most species showing statistical differences between tree and pasture plots tended to be significantly more abundant in pastures away from the tree, and only three species (Urtica urens, Chenopodium opulifolium, and Melica ciliata) showed a statistical preference for the area below the tree crown (Appendix S1; available online at http://dx.doi.org/10.2111/ REM-D-12-00016.s1). The mean richness values (S) were also greater (Student's $t, P<0.001$ ) in pasture plots than in tree plots $(S=15.02$ and 9.63 respectively). The total richness recorded in both types of communities, however, was very similar (72 compared with 69 species, respectively; Appendix S1). Pastures below trees had lower values of herbaceous cover and rabbit droppings and were covered more with holm oak scrub, cow dung and coarse litter (Table 2). The soil below the oak canopies tended to be darker and exhibited higher values of conductivity.

\section{Main Trends in Floristic Variation}

The influence of the trees on floristic variation can be observed mainly on axis III of the DCA ordination analysis (Fig. 1). Table 3 provides information about the differences in the mean 
Table 2. Mean values of the environmental variables that best discriminate pastures below the holm oak crown (tree) and away from it (pasture). The paired Student's $t$ test compares the values of variables in the two plots (below and away from the holm oak) of the same site. Variables favored by the tree are bold.

\begin{tabular}{|c|c|c|c|c|}
\hline & Tree & Pasture & Nonpaired Student's $t P$ Value $^{1}$ & Paired Student's $t P$ Value \\
\hline \multicolumn{5}{|l|}{ \% Cover } \\
\hline Bare soil & 26.79 & 20.41 & $\mathrm{NS}^{2}$ & 0.024 \\
\hline Herbaceous & 16.63 & 49.08 & $<0.001$ & $<0.001$ \\
\hline Total scrub & 8.32 & 5.51 & NS & NS \\
\hline Holm oak scrub & 5.16 & 2.01 & 0.017 & 0.001 \\
\hline Cow dung & 3.34 & 1.87 & 0.003 & $<0.001$ \\
\hline Rabbit pellets & 4.00 & 5.66 & 0.025 & 0.004 \\
\hline Oak leaf litter & 39.81 & 9.67 & $<0.001$ & $<0.001$ \\
\hline Other leaf litter & 1.07 & 1.28 & NS & $<0.001$ \\
\hline Catkins and twigs & 32.84 & 9.70 & $<0.001$ & $<0.001$ \\
\hline Total litter & 58.90 & 16.52 & $<0.001$ & $<0.001$ \\
\hline \multicolumn{5}{|l|}{ Edaphic variables of the plot } \\
\hline Darkness (0-10; pure black-pure white) & 4.800 & 5.190 & 0.003 & $<0.001$ \\
\hline Conductivity $\left(\mu \mathrm{S} \cdot \mathrm{cm}^{-1}\right)$ & 253.16 & 167.50 & 0.006 & $<0.001$ \\
\hline $\mathrm{pH}$ & 6.15 & 6.27 & NS & 0.016 \\
\hline
\end{tabular}

${ }^{1} t$ Student, $P<0.05$.

${ }^{2} \mathrm{NS}$ indicates not significant.

values of the coordinates between plots from the same site (paired Student's $t$ test) comparing tree and pasture groups. Topographical position was the variable that best explained the main variation trend (axis I) for the herbaceous communities (Table 4; Fig. 2), either considering all plots together or separately for tree and pasture plots $\left(r\right.$ Pearson $=0.463^{* *}$ and $0.366^{* *}$, respectively; ** indicates $\left.\mathrm{P}<0.001\right)$. Other variables that correlated with this axis were texture, conductivity, and cover of different types of litter. On one end of axis I, we found species that preferred more humid soils with a finer texture, such as Agrostis castellana, Poa bulbosa, Asteriscus aquaticus, and Carlina racemosa (Table 5), and at the opposite end species such as Bromus tectorum, Vulpia sp., Hypochoeris glabra, and Trifolium arvense, typical of poorer, sandier soils that desiccate faster (Gómez-Gutiérrez 1992; Rivas-Martínez et al. 2002).

TLP was the variable that best explained the second trend (axis II) revealed by the DCA analysis (Table 4, Fig. 3). The correlation of this variable with axis II was also significant when considering tree and pasture plots separately $(r$
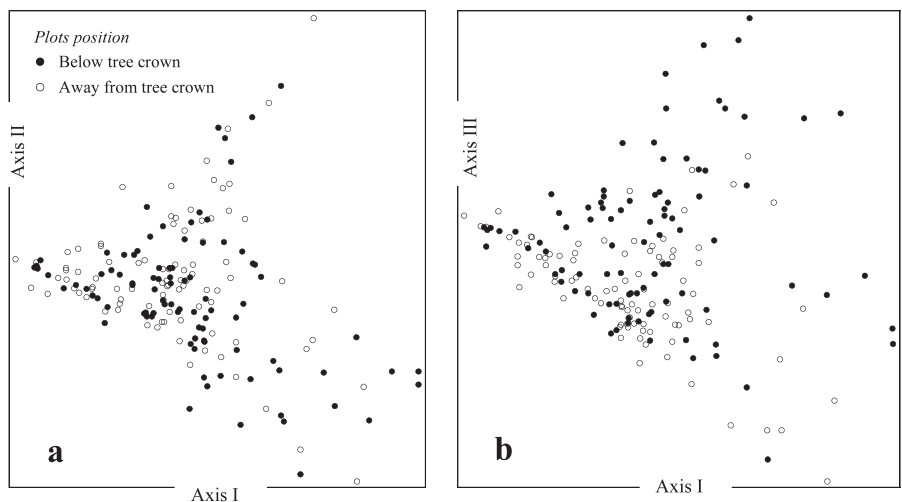

Figure 1. Position of the 182 plots on the plane comprising axes a, I-II and b, I-III of the ordination analysis (detrended correspondence analysis) based on floristic composition.
Pearson $=-0.572^{* *}$ and $-0.589 * *$, respectively). Significant correlations of this axis with other variables also suggested that the longer the time since the last plowing, the finer the soil texture and the greater the cover of scrub and of various litter components (Table 4).

Tree influence on herbaceous composition was best captured by DCA axis III, with a high percentage of tree plots tending to concentrate toward its positive end (Fig. 1b; Table 3). This idea was supported by a tendency of litter cover variables and soil darkness to increase along with the values of this axis (Table 4), with most of these variables being favored by the Holm oak canopy (Table 2). Most species positively correlated with axis III were nitrophilous: for example, Urtica urens, Hordeum murinum, Sisymbrium runcinatum, and Carlina racemosa (Table 5) (Rivas-Martínez et al. 2002).

\section{Influence of Holm Oak Cover on Herbaceous Community Variation}

Although the first two axes of the DCA suggested causes of variation other than the influence of trees, there were significant differences between the mean coordinates of tree and pasture plots within the same site (paired Student's $t$ test; Table 3), increasing from the first to the third axes. The higher relative value of the coordinate of tree plots on axis I compared to that of pasture plots of the same site indicated that floristic composition of pastures below trees was more similar to that of grasslands at lower zones of the topographical gradient (Fig. 2). Sixty percent of tree plots had a higher coordinate value on axis I than pasture plots in the same site.

In $63 \%$ of the sampled sites, tree plots presented a lower coordinate on axis II, compared to adjacent pasture plots, which in this case suggested that they had a floristic composition that was more similar to that showed by grasslands at more advanced successional stages, represented by TLP (Fig. 3). Also, $70 \%$ of tree plots had a higher coordinate value than pasture plots at the same site on axis 
Table 3. Variation explained by the first three axes of the detrended correspondence analysis ordination, mean plot coordinates below holm oaks (tree) and away from them (pasture) within the same site, and paired Student's $t$ test comparing these means.

\begin{tabular}{lcccr}
\hline & Explained variation (\%) & Mean coordinate of tree plots & Mean coordinate of pasture plots & Paired Student's $t$ \\
\hline Axis I & 14.7 & 157.38 & 141.96 & 2.622 \\
Axis II & 10.7 & 168.67 & 187.09 & -3.394 \\
Axis III & 7.1 & 207.25 & 165.68 & 0.010 \\
\hline
\end{tabular}

III, the axis that best reflected the influence of holm oak cover on pasture composition.

To further explore these trends, we correlated the differences between the coordinates of plots belonging to each of the sites with the differences in values of the different environmental variables in these plots (Table 6). The cover of shrubs and organic remains other than leaves (twigs, catkins) were the variables that best accounted for differences in tree and pasture plot coordinates on axis I related to topographical gradient. Of the variables considered in our study, none were significantly correlated with the differences in coordinates of plots on axis II of DCA related to TLP. The differences in cover of other organic remains, total litter, and cow dung between tree and pasture plots of the same site were significantly related to differences in coordinates of both types of plots on axis III related to the influence of holm oak.

\section{DISCUSSION}

\section{Overall Effect of Tree Cover and Environmental Conditions}

The results do not enable us to confirm that the effect of the trees on the floristic composition of pastures is greater in magnitude than other key ecological factors such as topogra-

Table 4. Environmental variables correlated with the coordinates of sampling plots on the three main axes of the ordination (detrended correspondence analysis). Correlation values ( $r$ Pearson) and their significance are shown. The letter $q$ indicates a significant quadratic relationship $(P<0.05)$ between the variable and the axis.

\begin{tabular}{|c|c|c|c|}
\hline Variables of the site & Axis I & Axis II & Axis III \\
\hline Topographical position & $0.433^{\star *}$ & $\mathrm{NS}^{1}$ & NS \\
\hline Time since last plowing & $q$ & $-0.574^{\star *}$ & NS \\
\hline Slope & $-0.177^{*}$ & NS & NS \\
\hline Tree cover (\%) & $-0.198 \star \star$ & NS & NS \\
\hline Scrub cover (\%) & $q$ & $-0.219 * *$ & NS \\
\hline Herbaceous cover (\%) & NS & $q$ & $q$ \\
\hline \multicolumn{4}{|l|}{$\%$ Covers of the plot } \\
\hline Oak leaf litter & $0.230 * \star$ & $-0.352^{\star \star}$ & $0.316^{\star *}$ \\
\hline Other leaf litter & $0.217 * \star$ & $-0.351^{\star \star}$ & $0.304^{\star *}$ \\
\hline Catkins and twigs & $0.310 * *$ & $-0.340^{* *}$ & $0.310 * \star$ \\
\hline Total litter & $0.287^{\star *}$ & $-0.378^{\star \star}$ & $0.340 * *$ \\
\hline Cow dung & NS & NS & $0.201^{* *}$ \\
\hline \multicolumn{4}{|l|}{ Edaphic variables of the plot } \\
\hline Texture (1-4; thicker-finer) & $0.245^{\star \star}$ & $-0.230 * *$ & $q$ \\
\hline Darkness (0-10; pure black-pure white) & NS & NS & $-0.164^{*}$ \\
\hline Conductivity $\left(\mu \mathrm{S} \cdot \mathrm{cm}^{-1}\right)$ & $0.301 * *$ & NS & NS \\
\hline
\end{tabular}

${ }^{1} \mathrm{NS}$ indicates not significant.

${ }^{\star} P<0.05 ;{ }^{*} P<0.01$ phy and the successional dynamics initiated after the land is plowed. Although the dispersed trees are seen as a relevant factor with regard to explaining the floristic variation in the pastures analyzed, topographic dynamics and plowing have a greater effect, as seen in their closer statistical relationship with the first two axes of the ordination analysis (Table 4). Other authors have found that these same factors determine the floristic composition of pastures with similar characteristics not influenced by tree cover (Pineda et al. 1981b; Casado et al. 1985). The results obtained in our study, however, show that the presence of trees attenuates the influence of these factors on the composition of the pastures.

The floristic composition of the herbaceous community of the tree plots bears a greater resemblance to pastures in lower slope zones than to pasture plots in the same site. If we accept that the floristic composition of the pastures responds to the ecological conditions of each site, our results show that the effect of tree cover, maintained as a regular framework, favors conditions similar to those in lower slope zones to a greater extent than it happens for adjacent pastures of open areas (see Fig. 2; Table 3). In a semiarid environment such as the one studied and with a sandy loam soil, the topographical gradient is closely associated with variation in soil moisture and with an increase in nutrient flow from the upper zones toward the lower ones (Puerto and Rico 1989, Gómez Gutierrez 1992). Our results are consistent with those of other authors who have studied the effects of holm oak trees upon soil moisture under the crown. For example, Joffre and Rambal (1993) found that, in subhumid dehesas in southern Spain, soil water content and water availability for plants is greater under trees than in the pastures of open areas. In contrast, other authors have found the opposite in semiarid dehesas in western Spain (Cubera and Moreno 2007). In our case, the effect of tree canopy may be acting at a finer scale. The tree and pasture plots in the same site exhibit differences in cover of leaves and other organic remains (see Table 6) which, together with the shading effect, may influence availability of water and nutrients and account for the differences in floristic composition.

\section{Plowing Implications}

TLP is the factor that best explains variation in the floristic composition of the pastures studied. As a traditional practice in silvopastoral systems, plowing alters nutrient dynamics and vegetation structure (Gómez-Sal et al. 1992). In dehesas, shifting cultivation of cereals in long-term rotations is part of rangeland management. The land is cleared of shrubs, cultivated for 2-3 yr and then abandoned for 7-8 yr. Thus plowing contributes to increased spatial heterogeneity in plant species composition at a landscape scale, as it favors the coexistence of pasture communities with differing successional stages (Pineda et al. 1981a). 


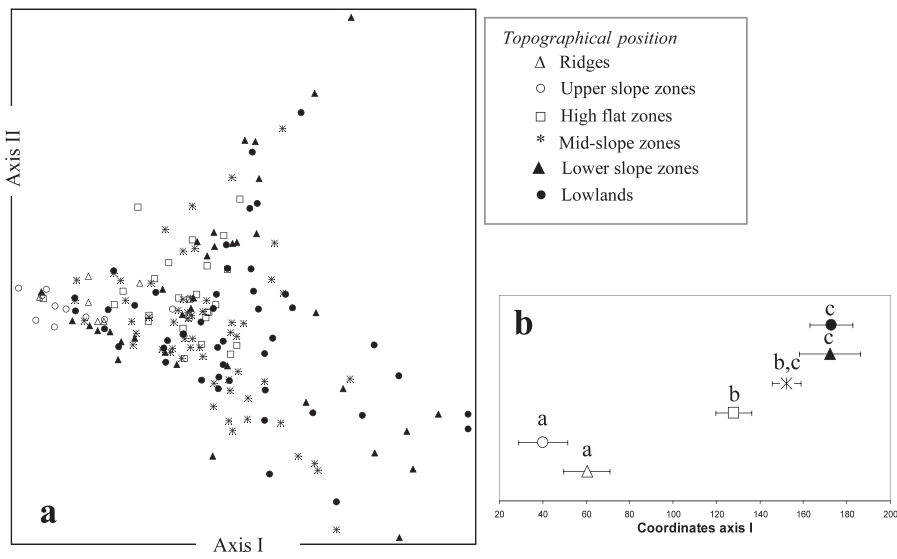

Figure 2. a, Position of the 182 plots on the plane comprising axes I and II of the ordination analysis (detrended correspondence analysis) based on floristic composition. The symbols correspond to six topographical categories according to a gradient of export-transport-accumulation of materials. $\mathbf{b}$, Mean coordinate values on axis I and standard error of each category. The letters indicate significant differences (ANOVA) between means.

In this management context, the overall effect of tree cover favored a different successional trajectory of tree plots in relation to pasture plots within the same site. In $63 \%$ of the sampled holm oaks, the floristic composition of the herbaceous community at tree plots was similar to that of plots where more years had passed since the last plowing event. In our study we found no variables significantly correlated with this trend (axis II, DCA), and further studies are therefore needed to fully understand this issue. We hypothesized that the shade of canopies may prevent the growth of heliophilous species such as Asteriscus aquaticus, Carduus pycnocephalus, Centaurea melitensis, or Andryala integrifolia, which are not present in the tree plots when a few years have passed since the last plowing event (see Appendix S1; Table 5).

\section{Specific Effect of Isolated Trees}

To date, the analysis of the individual effect of treesconsidered as isolated entities-in silvopastoral systems has not been differentiated from the general tree cover effects on pasture composition (Marañón et al. 2009; Fernández-Moya et al. 2011).

Our data suggest that the clearest effect of the holm oak, considered as an isolated tree, on the composition of these pastures is related to variables referring to selective livestock behavior under trees (resting, shading) and to the presence of litter and other organic remains in the soil (see Table 6). Several species indicating the canopy's effect (DCA axis III) are nitrophilous and subnitrophilous, associated with dung and overgrazing: Urtica urens, Hordeum murinum, Sisymbrium runcinatum, or Carlina racemosa (Tables 4 and 5). On the contrary, species characteristic of the other end of axis III (Poa bulbosa, Agrostis castellana, Erodium cicutarium, Astragalus pelecinus) indicate pastures subjected to a balanced grazing, or heliophilous species (Andryala integrifolia, Evax carpetana, Logfia minima, Herniaria cinerea) in a context of nutrient-poor soils (Rivas-Martínez et al. 2002).

Studies on the behavior of cattle in extensive farming on the same estate have highlighted the role played by trees in the
Table 5. Species correlated with the coordinates of the sampling plots on the three main axes of the ordination (detrended correspondence analysis). The values of correlation ( $r$ Pearson) and significance are shown.

\begin{tabular}{|c|c|c|c|}
\hline & Axis I & Axis II & Axis III \\
\hline Agrostis castellana & $0.465^{\star \star}$ & $-0.216^{\star *}$ & $-0.196^{\star \star}$ \\
\hline Anchusa undulata & $-0.175^{\star}$ & $N S^{1}$ & NS \\
\hline Andryala integrifolia & NS & $0.309 * *$ & $-0.239 * *$ \\
\hline Arenaria leptoclados & NS & 0.224 & NS \\
\hline Asteriscus aquaticus & $0.171^{*}$ & $0.393^{\star *}$ & $-0.239 * *$ \\
\hline Astragalus pelecinus & NS & NS & $-0.162^{\star}$ \\
\hline Brassica barrelieri & NS & $-0.215^{\star \star}$ & NS \\
\hline Bromus tectorum & $-0.635^{\star \star}$ & NS & NS \\
\hline Capsella rubella & NS & $-0.156^{\star}$ & NS \\
\hline Carduus pycnocephalus & NS & $0.368^{* *}$ & NS \\
\hline Carlina racemosa & $0.385^{\star *}$ & $-0.287^{\star *}$ & $0.146^{*}$ \\
\hline Centaurea melitensis & NS & $0.379 * *$ & $-0.226^{\star \star}$ \\
\hline Crepis capillaris & NS & NS & -0.196 ** \\
\hline Erodium cicutarium & NS & NS & -0.250 ** \\
\hline Evax carpetana & NS & $0.183^{\star}$ & -0.250 ** \\
\hline Filago pyramidata & NS & NS & $-0.185^{\star}$ \\
\hline Galium parisiense & NS & $0.243^{\star \star}$ & NS \\
\hline Herniaria cinerea & NS & NS & $-0.241 * *$ \\
\hline Hordeum murinum & NS & NS & $0.170^{\star}$ \\
\hline Hypochoeris glabra & $-0.207^{\star \star}$ & NS & NS \\
\hline Logfia minima & NS & NS & $-0.321^{* *}$ \\
\hline Melica ciliata & NS & $-0.282^{\star \star}$ & $0.279^{\star \star *}$ \\
\hline Poa bulbosa & $0.240 * *$ & $-0.361^{\star \star}$ & $-0.367^{\star *}$ \\
\hline Sisymbrium runcinatum & NS & $0.388^{* *}$ & $0.172^{\star *}$ \\
\hline Spergularia rubra & NS & NS & $-0.229 * *$ \\
\hline Taeniatherum caput-medusae & NS & $-0.334^{\star *}$ & NS \\
\hline Trifolium arvense & -0.212 & NS & NS \\
\hline Urtica urens & NS & NS & $0.402^{* *}$ \\
\hline Vulpia sp. & -0.355 & NS & NS \\
\hline
\end{tabular}

${ }^{1} \mathrm{NS}$ indicates not significant.

${ }^{\star} P<0.05 ;{ }^{*} P<0.01$.

behavior of cattle (Gómez-Sal et al. 1992; De Miguel et al. 1997). These animals commonly use the shade of some specific trees to rest during the hottest time of day, mainly during spring and summer (Gómez-Sal et al. 1992). This behavior accounts for the abundance of cow dung under the crowns of many of these trees and conditions pasture composition through its effect on soil nutrients and seed dispersal (Edwards and Hollis 1992; Malo and Suárez 1995; Ryrie and Prentice 2011).

Several authors have highlighted the role played by trees in increasing soil fertility associated with the input of litter (Hernández et al. 1992; Belsky 1994; Rhoades 1997; Gallardo 2003; Maltez-Mouro et al. 2005; Moreno 2008). In relation to productivity, however, results are contradictory. Some studies have detected a positive effect on primary production and abundance of grass species (Scholes and Archer 1997; Ovalle et al. 2006; Moreno and Obrador 2007; Treydte et al. 2007), but others have found negative effects of holm oaks on net primary production and herbage quality (Mosquera-Losada et al. 2005). In our case, a high number of the sampled holm oaks favored communities with low forage quality, with nitrophilous and unpalatable species predominating. However, the presence of 


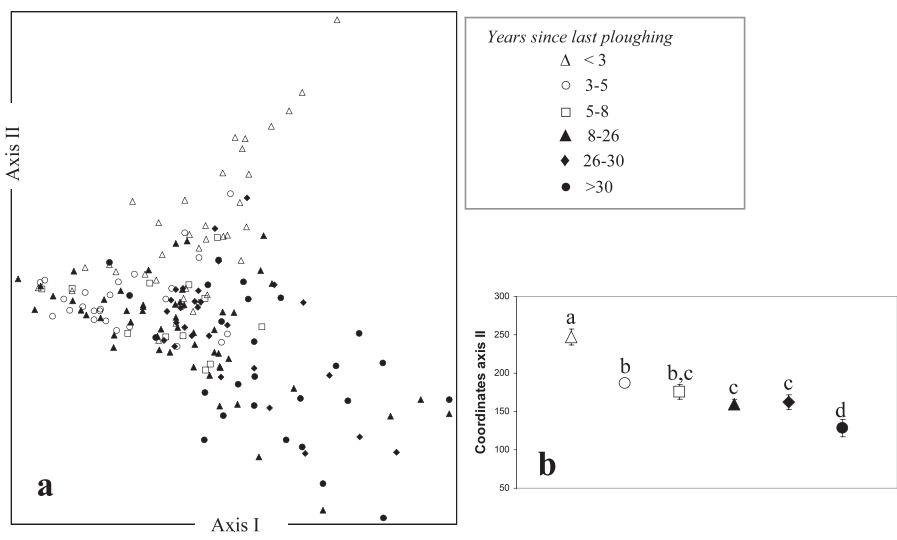

Figure 3. a, Position of the 182 plots on the plane comprising axes I and II of the ordination analysis (detrended correspondence analysis) based on floristic composition. The symbols correspond to 6 categories of time since the last plowing event. $\mathbf{b}$, Mean coordinate values on axis II and standard error of each category. The letters indicate significant differences (ANOVA) between means.

these species should be associated with the role played by trees as points of reference at which livestock tends to perform certain activities such as rumination and resting (De Miguel et al. 1997).

\section{IMPLICATIONS}

Our data indicate that the tree cover arranged in a regular pattern in the territory has the general effect of favoring development of a grassland floristic composition that is more similar to that of lower slope zones, where soil moisture and fertility are greater. This result is of particular relevance in semiarid environments such as those of the Mediterranean climates, especially in areas in which low-fertility soils (with low water and nutrient contents) pose important restrictions to free-range livestock production. Coupled with this, our analyses also detected an effect of individual trees indicated by the presence under tree canopies of some nitrophilous plants and variable values reflecting specific cattle activities such as dunging and resting, which suggest a differentiated role for each tree on grassland composition. This specific effect might be associated with intrinsic characteristics of the tree-for instance, position in the relief or morphology of the tree crown-or may be due to their relative position on the estate-for example, distance from specific areas used by livestock in their activities(Gómez Sal et al. 1992).

Our results therefore highlight the need to analyze the effects of trees in silvopastoral systems from two different perspectives: the overall effect of trees on the composition of the general herbaceous community as a factor acting at landscape scale, and the individual effect of trees considering a more detailed scale, related to the behavior of cattle. This result opens up a whole new perspective for management of silvopastoral systems, particularly in semiarid climates. It suggests the possibility of adapting the network of scattered trees-tree density, situation and shape of individuals-to the geophysical conditions of each estate and to the requirements of the livestock. This is an important issue, particularly bearing in mind the importance of these systems for both the
Table 6. Significant correlations ( $r$ Pearson) between the difference in coordinates of plots below (tree) and away (pasture) from the holm oak on the first three detrended correspondence analysis axes in the same site, and differences in the environmental variables recorded in these plots.

\begin{tabular}{lccc}
\hline & \multicolumn{3}{c}{$\begin{array}{c}\text { Difference in coordinate } \\
\text { tree-pasture plots }\end{array}$} \\
\cline { 2 - 4 } Difference in environmental variable values & Axis I & Axis II & Axis III \\
\hline Scrub cover & $0.222^{*}$ & NS & NS \\
Other litter components (not leaves) & $0.248^{*}$ & NS & $0.382^{* *}$ \\
Total litter & NS & NS & $0.320^{* *}$ \\
Cow dung & NS & NS & $0.284^{* *}$ \\
\hline${ }^{1}$ NS indicates not significant. & & & \\
${ }^{*} P<0.05 ;{ }^{*} P<0.01$. & & &
\end{tabular}

provision of high-quality products and nature conservation, and the fact that their viability is actually compromised due to ongoing land use changes and the low levels of tree regeneration detected in them (Ovalle et al. 1990; PintoCorreia and Mascarenhas 1999; Plieninger et al. 2003; Gómez-Sal and González-García 2007).

\section{ACKNOWLEDGMENTS}

We wish to thank Lucía Gálvez, Miguel A. Rodríguez, and two anonymous referees for comments that substantially improved the manuscript.

\section{LITERATURE CITED}

Belsky, A. J. 1994. Influences of trees on savanna productivity: tests of shade, nutrients, and tree-grass competition. Ecology 75:922-932.

Casado, M. A., J. M. De Miguel, A. Sterling, B. Peco, E. F. Galiano, and F. D. Pineda. 1985. Production and spatial structure of Mediterranean pastures in different stages of ecological succession. Vegetatio 64:75-86.

Cottingham, K., J. Lennon, and B. Brown. 2005. Knowing when to draw the line: designing more informative ecological experiments. Frontiers in Ecology and the Environment 3:145-152.

Cubera, E., and G. Moreno. 2007. Effect of single Quercus ilex trees upon spatial and seasonal changes in soil water content in dehesas of central western Spain. Annals of Forest Science 64:355-364.

De Miguel, J. M. 1999. Naturaleza y configuración del paisaje agrosilvopastoral en la conservación de la diversidad biológica en España. Revista Chilena de Historia Natural 72:547-557.

De Miguel, J. M., M. A. Rodríguez, and A. Gómez-Sal. 1997. Determination of animal behavior-environment relationships by correspondence analysis. Journal of Range Management 50:85-93.

Díaz, S., and M. Cabido. 1997. Plant functional types and ecosystem function in relation to global change. Journal of Vegetation Science 8:463-474.

Edwards, P. J., and S. Hollis. 1992. The distribution of excreta on new forest grassland used by cattle, ponies and deer. Journal of Applied Ecology 19:953964.

Escudero, A., B. García, J. M. Gómez, and E. Luis. 1985. The nutrient cycling in Quercus rotundifolia and Quercus pyrenaica ecosystems (dehesa) of Spain. Oecologia Plantarum 6:73-86.

Fernández-Moya, J., A. San Miguel-Ayanz, I. Cañellas, and G. Gea-Izquierdo. 2011. Variability in Mediterranean annual grassland diversity driven by small-scale changes in fertility and radiation. Plant Ecology 212:865-877.

Gallardo, A. 2003. Effect of tree canopy on the spatial distribution of soil nutrients in a Mediterranean dehesa. Pedobiologia 47:117-125. 
Gea-Izquierdo, G., B. Allen-Diaz, A. S. Miguel, and I. Canellas. 2010. How do trees affect spatio-temporal heterogeneity of nutrient cycling in Mediterranean annual grassland? Annals of Forest Science 67:112-122.

Gómez-Gutí́rRez, J. M. 1992. El libro de las dehesas salmantinas. Valladolid, Spain: Junta de Castilla y León. $941 \mathrm{p}$.

Gómez-Sal, A., and A. González-García. 2007. A comprehensive assessment of multifunctional agricultural land-use systems in Spain using a multi-dimensional evaluative model. Agriculture, Ecosystems and Environment 120:82-91.

Gómez-Sal, A., M. A. Rodriguez, and J. M. De Miguel. 1992. Matter transfer and land use by cattle in a dehesa ecosystem of Central Spain. Vegetatio 99-100:345354.

González-Bernáldez, F., M. Morey, and F. Velasco. 1969. Efectos de la encina sobre el pasto. Real Sociedad de Historia Natural (Biología) 67:265-284.

Hernández, I., J. F. Gallardo, I. Santa-Regina, and C. Quilchano. 1992. Decomposition rate of Quercus rotundifolia leaves in an evergreen oak forest of the Duero Basin (province of Zamora, Spain). Vegetatio 100:259-262.

HILL, M. O., AND H. G. GAUCH. 1980. Detrended correspondence analysis: an improved ordination technique. Vegetatio 42:47-58.

Joffre, R., AND S. Rambal. 1993. How tree cover influences the water-balance of Mediterranean rangelands. Ecology 74:570-582.

Jongman, R. H. G., C. J. F. ter Braak, and O. F. R. van Tongeren. 1995. Data analysis in community and landscape ecology. Wageningen, Netherlands: Pudoc. 300 p.

Le Houérou, N. H. 1981. Impact of man and his animals on Mediterranean vegetation. In: F. di Castri, D. W. Goodall, and R. L. Specht [EDs.]. Ecosystems of the world 11. Mediterranean-type shrublands. Amsterdam, Netherlands: Elsevier. p. 479-521.

LudwiG, F., H. De Kroon, ANd H. H. T. Prins. 2008. Impacts of savanna trees on forage quality for a large African herbivore. Oecologia 155:487-496.

Malo, J. E., and F. Suarez. 1995. Herbivorous mammals as seed dispersers in a Mediterranean dehesa. Oecologia 104:246-255.

Maltez-Mouro, S., L. V. Garcia, T. Marañón, and H. Freitas. 2005. The combined role of topography and overstorey tree composition in promoting edaphic and floristic variation in a Mediterranean forest. Ecological Restoration 20:668-677.

Manning, A. D., J. Fischer, and D. B. Lindenmayer. 2006. Scattered trees are keystone structures-implications for conservation. Biological Conservation 132:311-321.

Manning, A. D., P. Gibbons, and D. B. Lindenmayer. 2009. Scattered tress: a complementary strategy for facilitating adaptive responses to climate change in modified landscapes? Journal of Applied Ecology 46:915-919.

Marañon, T. 1986. Plant species richness and canopy effect in the savanna-like "dehesa" of S.W. Spain. Ecología Mediterránea 12(1-2):131-141.

Marañón, T. 1988. Agro-sylvo-pastoral systems in the Iberian Peninsula: dehesas and montados. Rangelands 10:255-258.

Marañón, T., F. I. Pugnaire, and M. Callaway. 2009. Mediterranean-climate oak savannas: the interplay between abiotic environment and species interactions. Web Ecology 9:30-43.

Martín, M. A., and R. Fernández-Alés. 2006. Long term persistence of dehesas. Evidences from history. Agroforestry Systems 67:19-28.

Moreno, G. 2008. Response of understorey forage to multiple tree effects in Iberian dehesas. Agriculture, Ecosystems and Environment 123:239-244.

Moreno, G., and J. J. Obrador. 2007. Effects of trees and understorey management on soil fertility and nutritional status of holm oaks in Spanish dehesas. Nutrient Cycling in Agroecosystems 78:253-264.

Mosquera-Losada, M. R., J. McAdam, and A. Rigueiro-Rodríguez. 2005. Silvopastoralism and sustainable land management. Wallingford, UK: CABI Publishing. $450 \mathrm{p}$.

OKSANEN, J., AND P. R. MINCHIN. 1997. Instability of ordination results under changes in input data order: explanations and remedies. Journal of Vegetation Science 8:447-454.

Olea, L., and A. San Miguel-Ayanz. 2006. The Spanish dehesa: a traditional Mediterranean silvopastoral system linking production and nature conservation. Grassland Science in Europe 11:3-13.
Ovalle, C., J. Aronson, A. del Pozo, and J. Avendaño. 1990. The Espinal-agroforestry systems of the Mediterranean-type climate region of Chile-state-of-the-art and prospects for improvement. Agroforestry Systems 10:213-239.

Ovalle, C., AND J. Avendaño. 1987. Interactions of the tree layer with herbaceous understory layer in the plant-communities of Acacia caven (Mol) Hook et Arn in Chile. 1. Tree influence on the botanical composition, production and phenology of the herbaceous stratum. Acta Oecologica-Oecologia Plantarum 8:385-404.

Ovalle, C., A. del Pozo, M. A. Casado, B. Acosta, and J. M. De Miguel. 2006. Consequences of landscape heterogeneity on grassland diversity and productivity in the espinal-agroforestry system of central Chile. Landscape Ecology 21:585-594.

Peco, B. 1989. Modelling Mediterranean pasture dynamics. Vegetatio 83:269-276.

Pérez-Ramos, I. M., M. A. Zavala, and T. Marañón. 2008. Dynamics of understorey herbaceous plant diversity following shrub clearing of cork oak forests: a fiveyear study. Forest Ecology and Management 255:3242-3253.

Pineda, F. D., And J. Montalvo. 1995. Dehesa systems in the western Mediterranean. In: P. Halladay and D. A. Golmour [EDS.]. Conserving biodiversity outside protected areas. Gland, Switzerland, and Cambridge, UK: IUCN. p. 107-122.

Pineda, F. D., J. P. Nicolas, A. Pou, and E. F. Galiano. 1981a. Ecological succession in oligotrophic pastures of central Spain. Vegetatio 44:165-176.

Pineda, F. D., J. P. Nicolas, M. Ruiz, B. Peco, and F. G. Bernáldez. 1981b. Niche succession, diversity and amplitude in grasslands at the centre of the Iberian Peninsula. Vegetatio 46-47:267-277.

Pinto-Correia, T., and J. Mascarenhas. 1999. Contribution to the extensificationintensification debate: new trends in the Portuguese montado. Landscape and Urban Planning 46:125-131.

Plieninger, T., F. Pulido, and W. Konold. 2003. Effects of land use history on size structure of holm oak stands in Spanish dehesas: implications for conservation and restoration. Environment Conservation 30:61-70.

Puerto, A., AND M. Rico. 1989. Influence of tree canopy (Quercus rotundifolia Lam. and Quercus pyrenaica Willd.) on old field succession in marginal areas of central-western Spain. Acta Oecologica-Oecologia Plantarum 9:337-358.

Reis, G., Â. Lana, R. Mauricio, R. Lana, R. Machado, I. Borges, and T. Neto. 2010. Influence of trees on soil nutrient pools in a silvopastoral system in the Brazilian Savannah. Plant and Soil 329:185-193.

RHOADES, C. C. 1997. Single-tree influences on soil properties in agroforestry: lessons from natural forest and savanna ecosystems. Agroforestry Systems 35:71-94.

Rivas-Martínez, T. E. D., F. Fernández-Gonzálezz, L. Loidi, and A. Penas. 2002. Vascular plant communities of Spain and Portugal. Itinera Geobotanica 15:433-922.

Ryrie, S. C., and I. C. Prentice. 2011. Herbivores enable plant survival under nutrient limited conditions in a model grazing system. Ecological Modelling 222:381397.

Sankaran, M., J. Ratnam, and N. P. Hanan. 2004. Tree-grass coexistence in savannas revisited insights from an examination of assumptions and mechanisms invoked in existing models. Ecological Letters 7:480-490.

Scholes, R. J., and S. R. Archer. 1997. Tree-grass interactions in savannas. Annual Review of Ecology and Systematics 28:517-544.

Sternberg, M., M. Gutman, A. Perevolotsky, E. D. Ungar, and J. Kigel. 2000. Vegetation response to grazing management in a Mediterranean herbaceous community: a functional group approach. Journal of Applied Ecology 37:224-237.

Tate, K. W., D. M. Dudley, N. K. Mcdougald, and M. R. George. 2004. Effect of canopy and grazing on soil bulk density. Journal of Range Management 57:411-417.

Treydte, A. C., I. M. A. HeitKönig, H. H. T. Prins, and F. Ludwig. 2007. Trees improve grass quality for herbivores in African savannas. Perspectives in Plant Ecology, Evolution and Systematics 8:197-205.

VetAAS, O. R. 1992. Micro-site effects of trees and shrubs in dry savannas. Journal of Vegetation Science 3:337-344. 